\title{
Caloplaca subpallida (Teloschistaceae), a lichen species new to Poland: distribution, ecology and taxonomic affinities
}

\author{
Katarzyna Szczepańska ${ }^{1 *}$, Maria Kossowska² ${ }^{2}$ Karina Wilk ${ }^{3}$ \\ ${ }^{1}$ Department of Botany and Plant Ecology, Wrocław University of Environmental and Life Sciences, pl. Grunwaldzki 24a, 50-363 Wrocław, Poland \\ ${ }^{2}$ Department of Biodiversity and Plant Cover Protection, University of Wrocław, Kanonia 6/8, 50-328 Wrocław, Poland \\ ${ }^{3}$ Laboratory of Lichenology, W. Szafer Institute of Botany, Polish Academy of Sciences, Lubicz 46, 31-512 Cracow, Poland
}

\begin{abstract}
Caloplaca subpallida is reported from basic and altered ultrabasic rocks (i.e. basalt, greenstone, and serpentinite) at nine sites in SW Poland. A detailed description of the species and a discussion on its taxonomic affinities are provided.
\end{abstract}

Keywords: lichenized fungi, Caloplaca oxfordensis, C. ferruginea group, lichen taxonomy, Sudety Mts

\section{Introduction}

Caloplaca subpallida, described from Europe by Magnusson [1], belongs to the C. ferruginea group [2,3], which includes species with whitish, greyish or blackish thalli lacking anthraquinones, and ferrugineous apothecia, which contain anthraquinones. The species of the group are characterized by their content of chemosyndromes based on 7-chloroemodin [4]. This is a large group of ca. 35 species [2,3], which have different habitat preferences, growing on siliceous or calcareous rocks, bark of trees, wood or bryophytes. According to Gaya et al. [5], the C. ferruginea group is polyphyletic and taxonomically very problematic; therefore the group is in urgent need of a thorough revision worldwide. However, some recent contributions to its understanding have been undertaken by Vondrák \& Hrouzek [6], Arup et al. [7] and Arup \& Åkelius [8].

The C. ferruginea group, represented by ca. 22 species in Poland [9-13], has not been subjected to detailed studies, although taxonomic notes on some species are included in the papers by Wilk \& Flakus [10], Wilk \& Śliwa [11] and Wilk [12], which refer to the following taxa: C. albolutescens (Nyl.) H. Olivier, C. conciliascens (Nyl.) Zahlbr., C. percrocata (Arnold) J. Steiner, C. soralifera Vondrák \& Hrouzek and C. teicholyta (Ach.) J. Steiner. Furthermore, the two first authors of the present study have paid special attention on this species group during lichenological studies in SW Poland. Based on these surveys,

* Corresponding author. Email: katarzyna.szczepanska@up.wroc.pl Handling Editor: Beata Zagórska-Marek

This is an Open Access digital version of the article distributed under the terms of the Creative Commons Attribution 3.0 License (creativecommons.org/licenses/by/3.0/), which permits redistribution, commercial and non-commercial, provided that the article is properly cited.
Kossowska [13] reported C. cf. atroflava (Turner) Mong. from serpentinites of the Sudety Mts and the Przedgórze Sudeckie foreland; more recent work has shown that $C$. subpallida was included in the material published by Kossowska [13], and subsequent studies carried out in the same area by the first author yielded additional records of the latter species.

In this paper, C. subpallida is reported as new to Poland, and a detailed description of the species with notes on its habitat and distribution are provided. Taxonomic affinities of the species with other taxa are discussed, with particular reference to $C$. oxfordensis based on the type material examination.

\section{Material and methods}

The study is based on material collected from the Sudety Mts (including the Pogórze Zachodniosudeckie foothills and the Przedgórze Sudeckie foreland) in SW Poland. Voucher material is lodged in WRSL and the private herbarium of K. Szczepańska (Hb. Szczepańska). Reference material from KRAM, MICH and MIN was also investigated.

Morphological characters were examined on dry material using a dissecting microscope and anatomical characters were observed on hand-cut sections and squash preparations mounted in water. The structure of paraphyses was observed in $25 \% \mathrm{KOH}(\mathrm{K}) . \mathrm{K}$ and $65 \%$ nitric acid $(\mathrm{N})$ were used for chemical reactions.

The terminology for tissues follows Bungartz [14] and Ryan et al. [15] and pigment nomenclature for non-anthraquinones follows Meyer \& Printzen [16].

\section{Results}

\section{Description of the species}

Caloplaca subpallida H. Magn., Bot. Not. 1945: 305. 
TYPE. Sweden, Bohuslän. Jorlanda, Rannekarr, 1939, Degelius (UPS; not seen).

Thallus epilithic, thin to thick, rimose at the periphery, rimose-areolate to subsqamulose in the central part, irregular in shape, pale to dark grey, epruinose; prothallus occasionally present, blackish; vegetative propagules absent. Areoles irregular, flat or slightly convex. Thallus cortex inconspicuous, ca. $15 \mu \mathrm{m}$ wide, paraplectenchymatous, the upper part $\mathrm{K}+$ and $\mathrm{N}+$ very weakly violet (sedifolia-grey pigment), without granules/ crystals; algal layer continuous.

Apothecia zeorine, numerous, usually crowded and in groups, at first partially immersed in the thallus, then broadly sessile, round to angular and flexuose due to mutual compression, $0.1-0.7 \mathrm{~mm}$ diam. (Fig. 1). Disc at first concave, then flat, orange to dark orange; proper margin persistent, thinner with age, at first raised above the disc, then at the same level with disc, smooth, distinctly paler than disc; thalline margin usually not visible macroscopically, occasionally present at base of apothecia. Parathecium well developed, prosoplectenchymatous, lumina of cells elongated, anthraquinone crystals present. Amphithecium with abundant algae, cortex indistinct, without granules/crystals. Epihymenium interspersed with orange-yellow crystals of anthraquinones (K+ red). Hymenium hyaline, 75-85(-110) $\mu \mathrm{m}$ high. Paraphyses simple to slightly branched, apical cells not thickened to slightly thickened, up to $5 \mu \mathrm{m}$ wide. Hypothecium hyaline, with irregular hyphae. Asci 8-spored, spores polarilocular, thin-walled, narrowly ellipsoid,
$(10-) 12-15.5(-19) \times(4.5-) 5-6.0(-7.0) \mu \mathrm{m}$, isthmus $2.5-4.0$ $\mu \mathrm{m}$ wide. Pycnidia not observed.

\section{Ecology and distribution}

Caloplaca subpallida grows on non-calcareous rocky substrata, especially mineral-rich siliceous rocks or slightly dustimpregnated surfaces, from boreal to Mediterranean regions [17]. In Poland, C. subpallida was recorded from basic and altered ultrabasic rocks (i.e. basalt, greenstone, serpentinite). These rocks are rich in compounds of $\mathrm{Ca}$ and $\mathrm{Mg}$, and relatively poor in silicon dioxide $\left(\mathrm{SiO}_{2}\right)$. At the collecting sites, the species was accompanied by silicicolous lichens with a wide range of habitat preferences [e.g. Acarospora fuscata (Nyl.) Arnold, Candelariella vitellina (Hoffm.) Müll. Arg., Lecanora muralis (Schreb.) Rabenh, Scoliciosporum umbrinum (Ach.) Arnold, Umbilicaria hirsuta (Sw. ex Westr.) Hoffm., Xanthoparmelia conspersa (Ach.) Hale], as well as lichens typical of neutral and slightly basic non-calcareous substrata [e.g. Lecanora rupicola (L.) Zahlbr., Lecidella carpathica Körb., Polysporina lapponica (Ach. ex Schaer.) Degel.], or metal- and mineral-enriched substrata [e.g. Catillaria atomarioides (Müll. Arg.) H. Kilias, Lecidea fuscoatra (L.) Ach., Rhizocarpon distinctum Th. Fr., Rinodina oxydata (A. Massal.) A. Massal. and Trapelia glebulosa (Sm.) J. R. Laundon]. It is worth noting that the occurrence of C. subpallida seems to be a characteristic trait of serpentinitic rocky substrata in SW Poland. Its typical lead-grey thalli were found on most of the exposed serpentinite outcrops (Fig. 2), sometimes constituting the dominant component of lichen

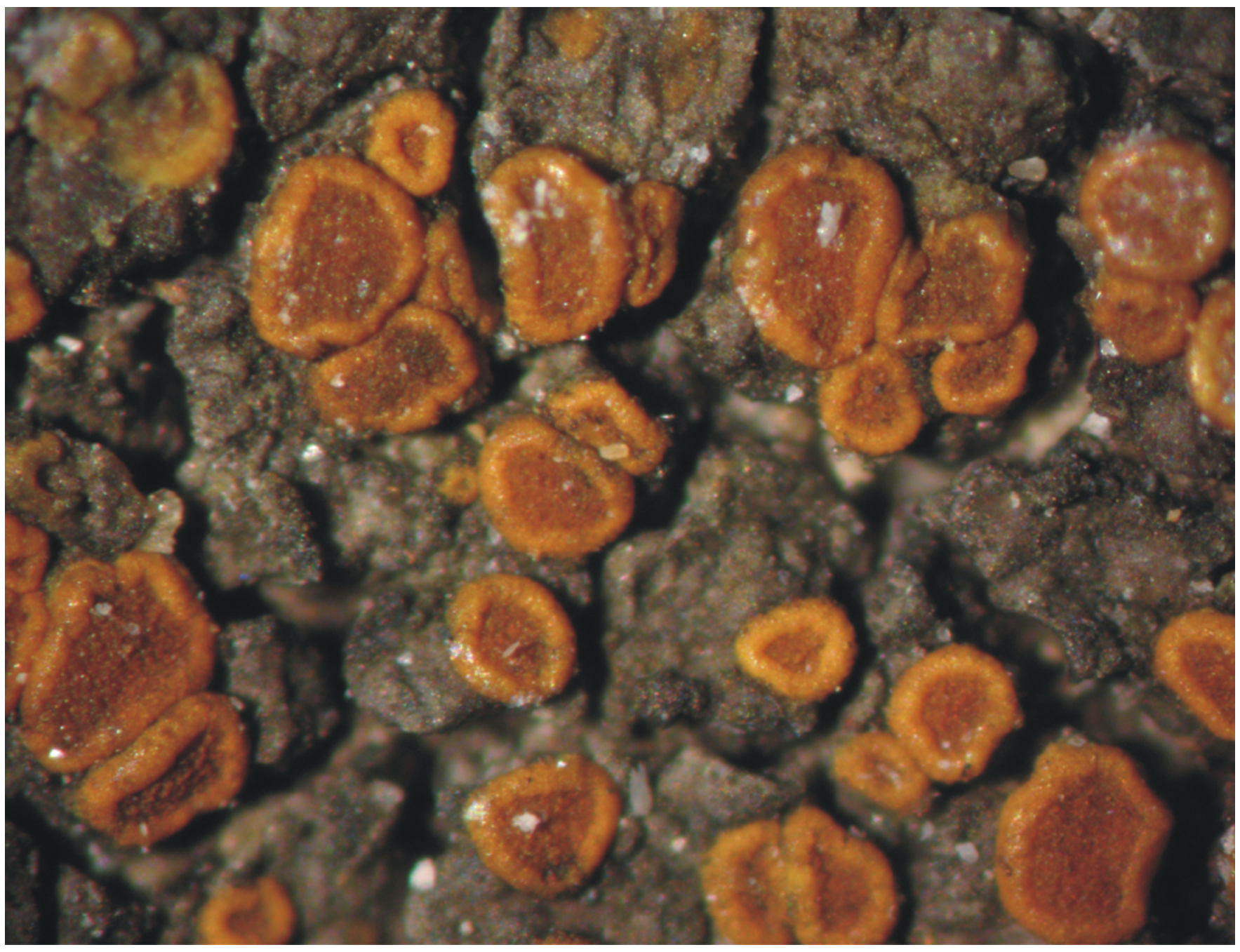

Fig. 1 Caloplaca subpallida, thallus with apothecia. 
vegetation [13]. Recent records of C. subpallida on basalt and greenstone, however, may reflect a wider ecological amplitude in the region. It is possible that under favorable environmental conditions, this lichen could be found also on other rocky substrata of similar mineralogical and chemical properties such as amfibolites and gabbro.

All known Polish localities of C. subpallida are concentrated in the SW of the country, within the Sudety Mts, including Przedgórze Sudeckie foreland and Pogórze Zachodniosudeckie foothills (Fig. 3), the nine collecting sites located in natural outcrops or abandoned quarries.

EXSICCATE EXAMINED. Vězda, Lich. Sel. Bohem. Exs. 110 (det. H. Magnusson; KRAM).

SPECIMENS EXAMINED. Poland, Pogórze Zachodniosudeckie foothills, Pogórze Kaczawskie foothills: Rataj hill, abandoned basalt quarry Małe Organy Myśliborskie, alt. 350 m, 2008 Aug 15, K. Szczepańska (Hb. Szczepańska); Pomocne village, greenstone outcrop next to church, alt. $380 \mathrm{~m}, 2008$ Oct 4, K. Szczepańska (Hb. Szczepańska). Przedgórze Sudeckie foreland, Ślęża Massif: Radunia Mt., serpentinite outcrop at the summit, alt. 573 m, 1999 Oct 29, M. Kossowska (WRSL); Swierczyna Mt., abandoned serpentinite quarry on the SE slope, 2000 Mar 24, M. Kossowska (WRSL); Świątniki village, abandoned serpentinite quarry ca. $1.5 \mathrm{~km}$ E of village, 2000 Oct 21, M. Kossowska (WRSL); Szczytna Mt., serpentinite outcrop at the summit, alt. 480 m, 2000 Apr 15, M. Kossowska (WRSL). Wzgórza Niemczańsko-Strzelińskie hills, Szklary village, abandoned serpentinite quarry, 2000 Jun 28, M. Kossowska (WRSL). Grochowa Massif, Brzeźnica Mt., serpentinite outcrop at the summit, 2000 Apr 8, M. Kossowska (WRSL). Sudety Mts, Góry Kaczawskie Mts, Janowice Stare village, abandoned serpentinite quarry above the village, 2000 Sep 19, M. Kossowska (WRSL).

REFERENCE MATERIAL SEEN. C. subpallida: Sweden, Västmanland County, Arboga, Landuberget, 1951 Sep 10, G. Kjellmert (MIN 735455); The Czech Republic, Protected Landscape Area Křivoklátsko, Tytersky stream valley, Valachov nature reserve, 2005 Apr 23, M. Kukwa 3910 (KRAM). C. oxfordensis: USA, Ohio, Butler Co., near Oxford, 1909 Aug 9, Fink (MICH!, holotype, isotype).

\section{Discussion}

Caloplaca subpallida is a taxonomically difficult European species, its position being discussed for decades (e.g. [18]). In the 1990s, it was regarded as a member of the C. sideritis group and synonymized with C. oxfordensis Fink [19], the taxon described from North America. Subsequently, the latter species was reported from several European countries, e.g. Austria [20], France [21], Greece [22] and Germany [23]. However, according to Arup [24], recent molecular studies reveal that C. oxfordensis and C. subpallida are two distinct species.

The studied material of C. subpallida is homogeneous, and morphologically and anatomically identical to Vězda's

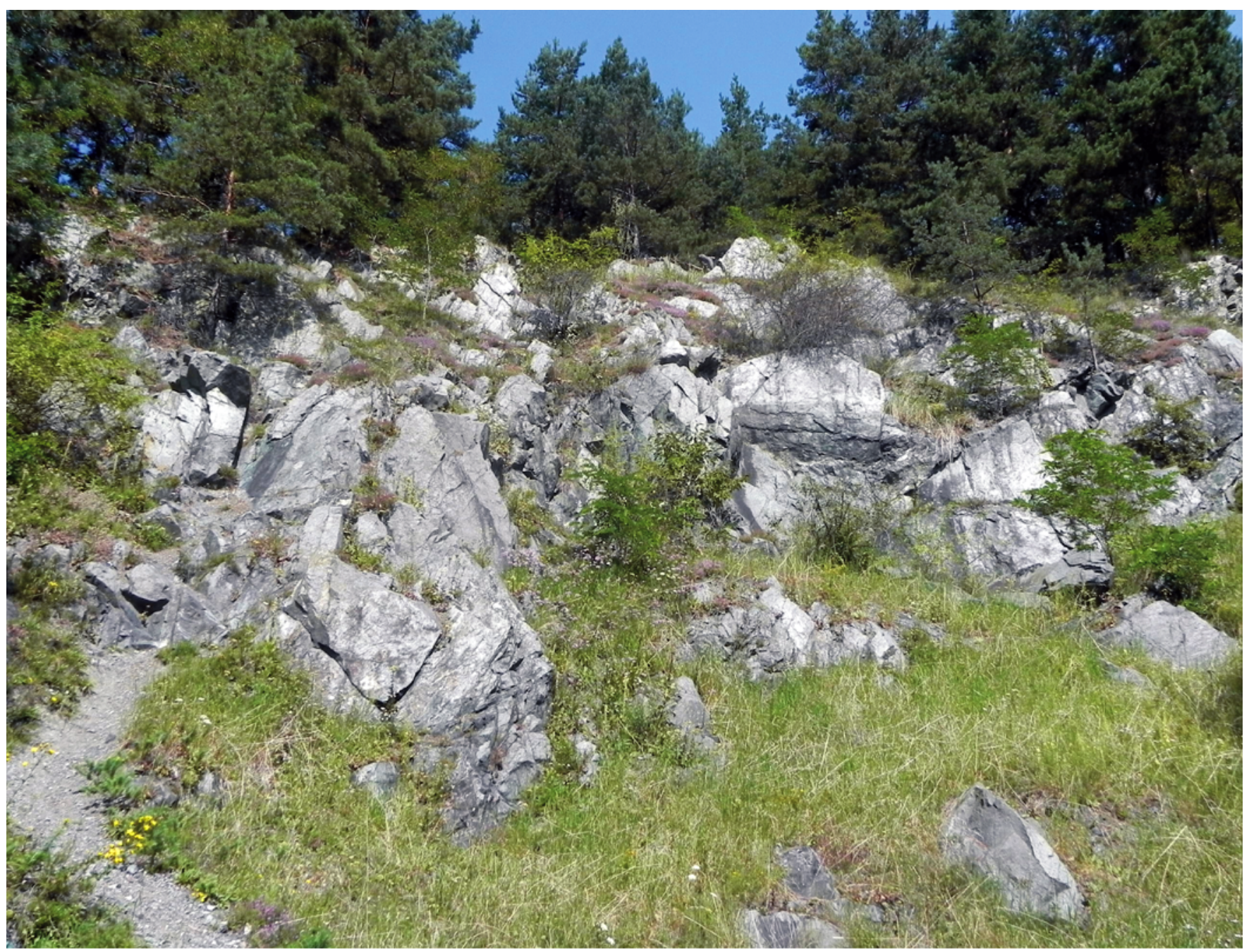

Fig. 2 Abandoned serpentinite quarry at Świerczyna Mt. as a typical habitat of Caloplaca subpallida. 


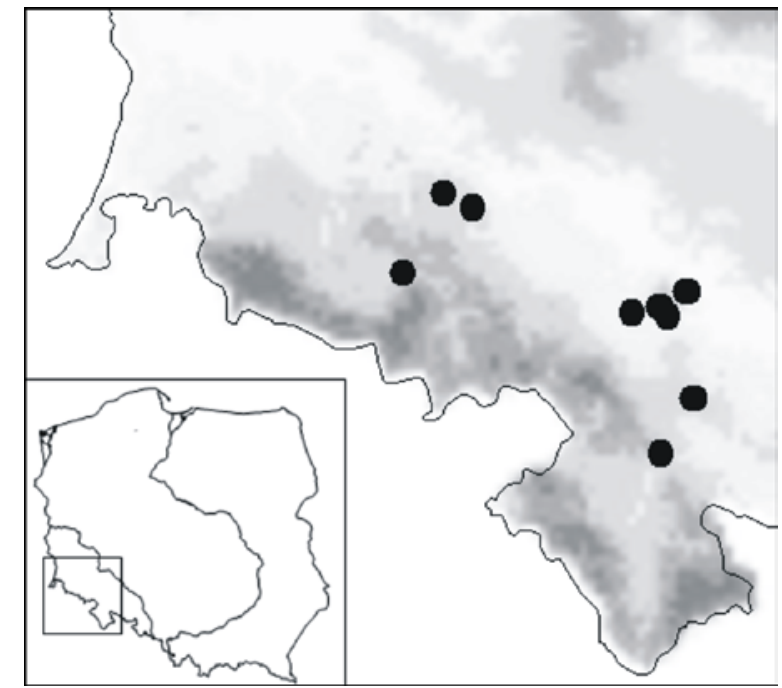

Fig. 3 Known localities of Caloplaca subpallida in Poland.

exsiccate specimen of C. subpallida determined by Magnusson. The species is characterized by its grey, rimose-areolate to subsquamulose thallus, and distinctly orange apothecia, usually without grey thalline margins. The apothecia are broadly sessile on the thallus, grouped and usually flexuose due to mutual compression. The spores are narrowly ellipsoid and its isthmus is moderately wide, $2.5-4.0 \mu \mathrm{m}$. It is worth noting that a comparison of C. subpallida with the type material of $C$. oxfordensis revealed that the anatomy of apothecia of both taxa is very similar, but the thallus development varies significantly, being thick and distinct in C. subpallida and extremely thin and almost invisible in C. oxfordensis. Although morphological evidence for separating the two species is not strong, their distinction is confirmed by molecular data [24].

Alternatively, C. subpallida was considered by some authors as conspecific with C. arenaria (Pers.) Müll. Arg. [25,26]. The latter species, however, differs from $C$. subpallida by its very thin or endolithic thallus, reddish-brown apothecia constricted at the base and usually scattered (rarely also in groups). C. atroflava is another similar species, but is distinguished by its distinctly widely ellipsoid spores $(14-17 \times 8-10 \mu \mathrm{m})$ with wider isthmus (6-8 $\mu \mathrm{m})$, and thinner, blackish-grey thallus, often with a faint violet shade [2]. According to Arup [24], C. subpallida is related to C. tristiuscula H. Magn., but the latter species can be distinguished from C. subpallida by its apothecia with both proper and thalline margins, usually clearly visible macroscopically, and thicker, larger and more verruculose thalli $[2,24]$.

\section{Acknowledgments}

We are grateful to Dr. L. Śliwa (Kraków, Poland) and Professor Mark Seaward (Bradford, U. K.) for providing valuable suggestions for improving the manuscript, to Dr. M. Kukwa (Gdańsk, Poland) for sending us a reference material of the species, to the curators of the herbaria, KRAM, MICH and MIN for the loan of material for study, and to two anonymous reviewers for critical comments and corrections. The study was funded by Department of Botany and Plant Ecology, Wrocław University of Environmental and Life Sciences, and Department of Biodiversity and Plant Cover Protection, University of Wrocław.

\section{Authors' contributions}

The following declarations about authors' contributions to the research have been made: field researches: KS, MK; determination of the specimens: KS, KW, MK; taxonomic analyses: $\mathrm{KW}$; writing of the manuscript: KS, KW, MK; preparation of the distribution map: MK; photographs: KS, MK.

\section{References}

1. Magnusson AH. New or interesting Swedish lichens XII. Bot Not. 1945:304-314.

2. Magnusson AH. Studies in the ferruginea-group of the genus Caloplaca. Göteborgs Kungl Vetenskaps- och Vitterhets-Samhälles Handlingar Sjätte Följden Ser B. 1944;3(1):1-71.

3. Clauzade G, Roux C. Likenoj de okcidenta Europo. Ilustrita determinlibro. Bull Soc Bot Centre-Ouest. 1985;7(n.s.):1-893.

4. Søchting U, Tønsberg T. Caloplaca xanthostigmoidea (Räs.) Zahlbr., a common lichen in cool regions of the Northern Hemisphere. Symb Bot Ups. 1997;32(1):247-253.

5. Gaya E, Navarro-Rosinés P, Llimona X, Hladun N, Lutzoni F. Phylogenetic reassessment of the Teloschistaceae (lichen-forming Ascomycota, Lecanoromycetes). Mycol Res. 2008;112(5):528-546. http://dx.doi.org/10.1016/j. mycres.2007.11.005

6. Vondrák J, Hrouzek P. Caloplaca soralifera, a new species from Europe. Graphis Scripta. 2006;18(1):6-15.

7. Arup U, Arneng E, Søchting U. Caloplaca fuscorufa - a misunderstood species in northern Europe. Lichenologist. 2007;39(5):409-414. http:// dx.doi.org/10.1017/S0024282907007098

8. Arup U, Åkelius E. A taxonomic revision of Caloplaca herbidella and C. furfuracea. Lichenologist. 2009;41(5):465-480. http://dx.doi.org/10.1017/ S0024282909008780

9. Fałtynowicz W. The lichens, lichenicolous and allied fungi of Poland - an annotated checklist. Cracow: W. Szafer Institute of Botany, Polish Academy of Sciences; 2003.

10. Wilk K, Flakus A. Four species of Caloplaca (Teloschistaceae, lichenized Ascomycota) new to Poland. Mycotaxon. 2006;96:61-71.

11. Wilk K, Śliwa L. Note on Caloplaca soralifera (Teloschistaceae, lichenized Ascomycetes) in Poland. Acta Soc Bot Pol. 2012;81(1):61-63. http://dx.doi. org/10.5586/asbp.2012.008

12. Wilk K. Calcicolous species of the genus Caloplaca in the Polish Western Carpathians. Polish Bot Stud. (in press)

13. Kossowska M. Epilithic lichens on serpentinite rocks in Poland. Polish Bot J. 2001;46(2):191-197.

14. Bungartz F. Morphology and anatomy of the fertile structures. In: Nash III TH, Ryan BD, Gries C, Bungartz F, editors. Lichen flora of the Greater Sonoran Desert Region. I. Lichens unlimited. Tempe AZ: Arizona State University; 2002. p. 24-35.

15. Ryan BD, Bungartz F, Nash III TH. Morphology and anatomy of the lichen thallus. In: Nash III TH, Ryan BD, Gries C, Bungartz F, editors. Lichen flora of the Greater Sonoran Desert Region. I. Lichens unlimited. Tempe AZ: Arizona State University; 2002. p. 8-23.

16. Meyer B. Proposal for a standardized nomenclature and characterization of insoluble lichen pigments. Lichenologist. 2000;32(6):571-583. http:// dx.doi.org/10.1006/lich.2000.0294

17. Wirth V. Die Flechten Baden-Württembergs. 2nd ed. Stuttgart: Ulmer; 1995. (vol 1).

18. Nimis PL. The lichens of Italy. An annotated catalogue. Turin: The Turin Museum of Natural History; 1993. (Monografie; vol 12).

19. Wetmore CM. The Caloplaca sideritis group in North and Central America. Bryologist. 1996;99(3):292. http://dx.doi.org/10.2307/3244301

20. Hafellner J, Obermayer W. Flechten und lichenicole Pilze im Gebeit 
der Stubalpe (Österreich: Steiermark und Kärnten). Mitt Naturwiss Ver Steiermark. 2007;136:5-59.

21. Roux C, Coste C, Bricaud O, Bauvet C, Masson D. Lichens et champignons lichénicoles du parc national des Cévennes (France). 5 - Vue d’ensemble et conclusion. Bull Soc Linn Provence. 2008;59:243-279.

22. Vondrák J, Guttová A, Mayrhofer H. A further contribution to the knowledge of lichen-forming and lichenicolous fungi in Crete. Herzogia. 2008;21:105-124.

23. Kanz B, Dürhammer O, Printzen C. Lichens and lichenicolous fungi of the Bavarian Forest. Preslia. 2005;77:355-403.

24. Arup U. Contributions to the knowledge of Caloplaca in the Nordic countries. Graphis Scripta. 2011;23:10-20.

25. Vondrák J, Etayo J. A contribution to the diversity of lichen-forming and lichenicolous fungi in the Spanish Pyrenees. Herzogia. 2007;20:189-198.

26. Fletcher A, Laundon JR. Caloplaca Th. Fr. (1860). In: Smith CW, Aptroot A, Coppins BJ, Fletcher A, Gilbert OL, James PW, et al., editors. The lichens of Great Britain and Ireland. London: British Lichen Society; 2009. p. 245-273. 